\title{
Erratum to: Usefulness of Clinical Signs and Diagnostic Tests for Suspected Leaks in Bariatric Surgery
}

\author{
I. Arteaga-González • A. Martín-Malagón • J. Martín-Pérez • \\ A. Carrillo-Pallarés
}

Published online: 13 March 2015

(C) Springer Science+Business Media New York 2015

\section{Erratum to: Obes Surg}

DOI 10.1007/s11695-015-1589-7

There are errors in the Results section of the Abstract. The last sentence of the section should read as follows:

In patients with a clinical suspicion of leakage $(n=19), 7.7 \%$ of abdominal CT scans returned false negatives versus $28.6 \%$ for oral methylene blue and $22.2 \%$ for upper gastrointestinal (UGI) Gastrografin swallow.

The online version of the original article can be found at http://dx.doi.org/ 10.1007/s11695-015-1589-7.

I. Arteaga-González • A. Martín-Malagón · J. Martín-Pérez ·

A. Carrillo-Pallarés

Department of Surgery, University Hospital of Canaries (HUC),

Santa Cruz de Tenerife, Spain

I. Arteaga-González

e-mail: ivanhuc@hispavista.com

A. Martín-Malagón

e-mail: ammalagon@hotmail.com

A. Carrillo-Pallarés

e-mail: acarrillo.md@gmail.com

J. Martín-Pérez ( $\square)$

Secretaría del Departamento de Cirugía (7a planta), Hospital

Universitario de Canarias, C/ Ofra, s/n. La Cuesta, La Laguna,

Tenerife 38320, Spain

e-mail: yessi6501@gmail.com 